\title{
HOW POTENTIAL EMPLOYERS APPROACH DISABILITY: A SURVEY OF LAW STUDENTS IN GEORGIA
}

\author{
E. Ann Puckett ${ }^{*}$
}

\section{Review of the Literature}

When I set out to discover how potential employers of law students approach issues of disability in their interviews, I did not expect to find a great deal of published information on the topic. The result was even more sparse than I expected. I only found one somewhat relevant article, a transcript of a roundtable discussion on lawyers with disabilities. ${ }^{1}$ The roundtable participants, most of whom had a disability, recounted their own experiences. One attorney told of being asked in a job interview about "how I would get around my disability in the courtroom.". He went on to say, "I did not know that that was not an appropriate question. I think lawyers interviewing an attorney today would not ask a question like that." ${ }^{3}$ Two other attorneys were flatly told that they would not be able to try cases in the courtroom because their disabilities would make them ineffective. ${ }^{4}$ One began litigating in his first full-time job and was very successful. ${ }^{5}$ The other was sequestered in the banking law division of his law firm because "they didn't see me as a lawyer in the courtroom, even though I was good at those kinds of things." ${ }^{\prime 6} \mathrm{He}$ left the firm to work in the attorney general's office and has argued more than forty cases in the appellate courts in the past ten years. He said he likes doing something that other lawyers thought he would not be able to do. ${ }^{7}$

Several of the panelists emphasized the importance of a good attitude, sometimes to the point of sounding like "supercrips." One woman told of getting up at 5:00 a.m. every day to get ready for work, but making sure her

\footnotetext{
* Professor of Law and Director of the Law Library, University of Georgia School of Law. Professor Puckett teaches a seminar in disability law.

1. Roundtable, Ready, Willing and Able, ARIZ. AtT'Y, Dec. 2002, at 10, available at http:// www.myazbar.org/AZAttorney/PDF_Articles/AZAT1202Round.pdf.

2. Id. at 12 .

3. Id.

4. See id. at $19,20$.

5. Id. at 19 .

6. See id. at 20.

7. See id.
} 
employer did not know she had to get up that early. ${ }^{8}$ Others talked about the responsibility lawyers with disabilities have to educate the non-disabled people around them and to sell themselves. "Bottom line, it comes down to the individual's attitude toward their particular condition, how they handle it." " "Selling yourself' is particularly important for disabled law students to develop interviewing skills and how to put the other person at ease with the fact that you have a disability." 10

The panelists were remarkably tolerant of ignorance and even bias on the part of non-disabled interviewers. For instance, one attorney who is often offered assistance by strangers even though he does not need it advised law students not to react negatively because "they're going to go away thinking that everyone in a wheelchair has got an attitude." "11 He went even further and said that he sometimes accepts help he does not need just to make the one who offered it feel good. ${ }^{12}$ He ends his advice this way: "Make them feel comfortable. Don't abuse them or be rude to them. Look at it as a learning process for them." 13

Occasionally, though, the panelists verbalized their frustration at being treated as stereotypes. One panelist, who is a prosecutor, was irritated when people assume he does disability cases or civil-rights cases. He said, "The work that I do as a lawyer has absolutely nothing to do with my disability." 14 Another recognized that disability is a social construct as much as it is an individual characteristic: "I believe that the problem of blindness is not the lack of eyesight. ... The real problem with blindness is society's attitudes about blindness." 15

Because of the paucity of articles about disability in the interviewing process, I broadened my inquiry to look at the interviewing experiences of law students in other traditionally disfavored groups. I found a number of articles dealing with the experiences of women, racial minorities, and lesbian and gay law students in job interviews.

A 1980 graduate of the University of Texas School of Law recalled a senior partner telling a female law student that he knew women could try

\footnotetext{
8. $\quad$ See id.

9. Id. at 15 .

10. Id. at 12,15 .

11. Id. at 21 .

12. See id.

13. Id.

14. Id. at 20 .

15. Id. at 16 .
} 
lawsuits but thought that they could not be rainmakers. ${ }^{16}$ Another interviewer said that hiring "cute women" allowed for natural attrition because they get married, have babies, and quit the firm. ${ }^{17}$ A 1951 graduate, whose picture was on the front page of the Houston Post as a "lone female in a sea of men," received a call from a Houston attorney offering her a job as a legal secretary. ${ }^{18}$ When she told him she planned to practice law with a west Texas firm, he became irate and told her she should confine herself to being a secretary. ${ }^{19}$

A 1975 graduate, a product of the era when women were first being admitted to law schools in significant numbers, reported some of the interview stories that discouraged her from interviewing at law firms. One classmate was asked if she would breast-feed her children and whether her husband resented her high law school grades. ${ }^{20}$ Playing it safe, the 1975 graduate decided to interview at the attorney general's office where she had clerked. ${ }^{21}$ During the interview she was told, "[W] checked on your clerkship with [the] person who was chief of that department at that time and he said, 'I would never hire a woman, but if I was ever going to hire a woman, Myra is the only woman I would hire."'22 She got the job anyway.

Up into the 1980s, women still reported being told that they could be hired to do research but not litigation because juries, judges, and clients do not "relate well to women." 23 A short, blonde, perky female, a 1981 graduate, was asked if she found it difficult being both short and female. ${ }^{24}$ Another was interviewed for a litigation position in a law firm because (she learned later) her first name was gender ambiguous. When the interviewer realized she was female, he told her he did not think women could litigate. ${ }^{25}$

People of color, men and women alike, tell of experiences similar to those recounted above. One interviewer asked an African-American candidate why the firm should hire an African-American now, after a long history of having

16. Our Place in History: A Celebration of Women in the Law at the University of Texas School of Law, 8 Tex. J. Women \& L. 331, 332 (1999).

17. Id.

18. Id. at 341

19. Id.

20. Id. at 349 .

21. Id.

22. Id. at $349-50$.

23. Id. at 352

24. Id. at 356 .

25. $I d$. 
no African-American lawyers. ${ }^{26}$ African-American candidates encounter more subtle forms of bias too, such as when interviewers assume that they will not be interested in the same social activities as white lawyers, ${ }^{27}$ or where other lawyers assume a minority lawyer is not as qualified as a white lawyer. ${ }^{28}$ One anecdote told of an African-American female who received high marks from all the interviewers except one older white male who found her "too aggressive." ${ }^{29}$ She was eliminated, while two white males with lower grades and negative interviewer reviews were hired. ${ }^{30}$

Many minority lawyers complain of the pervasive stereotypes they encounter. Asian-American men believe that they are often regarded as meek. ${ }^{31}$ They also believe that they encounter the reverse of the stereotype African-Americans report (that African-Americans are weak academically and have their jobs solely because of affirmative action). ${ }^{32}$ Asian-Americans, by contrast, are expected to excel academically. When they are merely average students, they believe they are treated worse than average white students. ${ }^{33}$

Sometimes, the interviewing student thinks she is just needed as a statistic. One African-American woman put it rather humorously: "[I felt] like people saw me as a 'two-check' on their NALP [National Association for Law Placement] form-African American and female - and that they were just itching to ask me if I were lesbian or had any disabilities because that would have been a bigger bargain - four checks for the price of one." 34

Lesbian, gay, bisexual, and transgendered law students have their own interview stories to tell. Like people with hidden disabilities, people of minority sexual orientations often wonder whether to disclose, and if they decide to disclose, when to disclose. One determined young woman undertook an experiment to determine the effect of disclosure on her career options. ${ }^{35}$ In half of her on-campus interviews, she submitted a full resume showing her gay rights activities; while in the other half, she described the gay

26. Minnesota Supreme Court Task Force on Racial Bias in the Judicial System, 16 HamLINE L. REv. 477, 678 (1993).

27. Id.

28. See id. at 679.

29. Id. at 680

30. Id.

31. H.S. Lee, Law Students of Color Speak on Recruiting, N.Y.L.J. May 3, 1999, at T1.

32. Id. at T10.

33. Id.

34. Id. at T11.

35. Bobbi Bernstein, When Good Intentions Aren't Enough: Observations of an Openly Gay Law Firm Applicant, 6 LaW \& SeXuality 127 (1996). 
rights work in more general human rights terms. ${ }^{36}$ In the interviews themselves, she talked openly about her sexual orientation with the interviewers who had the full resume, while she invited no discussion of her personal life with the interviewers who had the sanitized resume. ${ }^{37}$ Against her expectations, she found she suffered no disadvantage in disclosing her sexual orientation in the interviews, and in fact, she thought disclosure might have worked to her benefit. ${ }^{38}$ However, one interviewer who had told her a callback was "all-but-guaranteed" later sent a rejection letter. ${ }^{39}$ When she called to ask why, he gave a series of unconvincing reasons. ${ }^{40}$ In the course of the conversation, he seemed to reveal one possible reason for the rejection:

If you came to work for the firm, and two years later got a bad evaluation, would you immediately assume that the evaluation was the result of anti-gay discrimination? I don't know that this was a factor, . . . but I wouldn't be surprised if some people on the hiring committee had this concern in mind. ${ }^{41}$

Despite this experience, the author of the article remained convinced that law firm interviewers had good intentions but lacked information about what constitutes discrimination on the basis of sexual orientation. ${ }^{42}$

The Los Angeles County Bar Association undertook to study the level of sexual orientation discrimination among its members in light of the fact that such discrimination violates both California law and the California Rules of Professional Conduct. ${ }^{43}$ One in seven attorneys reported that his or her employer engaged in discrimination on account of sexual orientation. ${ }^{44}$

This study found that sexual orientation discrimination was much less subtly expressed than other types of bias. Some sample quotations from interviewers follow.

We (I) do not believe we (I) have to hire gay or lesbian attorneys - ever. . . Don't have any; don't want any. ${ }^{45}$

36. Id. at 128.

37. Id.

38. Id.

39. Id. at 138

40. See id.

41. Id. at 139 (internal quotation marks omitted).

42. Id.

43. The Los Angeles County Bar Association Report on Sexual Orientation Bias, 4 S. CAL. Rev. L. \& Women's Stud. 297 (1995).

44. Id. at 297.

45. Id. at 312 (internal quotation marks omitted). 
We do not seek out [gay] applicants and have no interest in hiring them. ... We are not interested in lawyers with that type of disability - a mental and emotional problem of obvious magnitude. ${ }^{46}$

We will not hire [gay attorneys]. . . . We have discussed the issue and how to prevent having them as lawyers. ... I and the rest of the firm do not want to work with them. ${ }^{47}$

One after another, the survey respondents described systematic and often overt bias against interviewing and hiring gay attorneys. Having a gay advocacy group on their resume was enough to get the interview terminated, in the experience of one lawyer. ${ }^{48}$ Another said that when he or she was seeking to change firms, "a number of firms . . . made it clear how unpleasant it would be [because I am gay]." ${ }^{49}$ Many survey respondents reported being advised to remain in the closet, being denied advancement because of their sexual orientation, and being the object of blatant homophobic comments, in addition to many other adverse experiences because of their sexual orientation. ${ }^{50}$

The articles discussed in the paragraphs above highlight the continuing struggles faced by disfavored groups to bring diversity to the practice of law. The American Bar Association (ABA) is beginning to address disability as another aspect of diversity. The ABA and the federal Equal Employment Opportunity Commission (EEOC) co-sponsored the first National Conference on the Employment of Lawyers with Disabilities in May 2006. ${ }^{51}$ The conference brought together recognized experts from around the country, including several who were at this symposium, for two main purposes: "(1) to facilitate the hiring of lawyers with disabilities, and (2) to help implement Goal IX, which commits the ABA and all its many entities to promote the participation of lawyers with disabilities, women, and racial and ethnic minorities in the legal profession. $" 52$

The keynote speaker for the conference was Richard L. Thornburgh, the United States Attorney General under President George H.W. Bush, who was very instrumental in the development and passage of the Americans with

\footnotetext{
46. Id. (internal quotation marks omitted).

47. Id. (internal quotation marks omitted).

48. See id. at 446.

49. Id. at 443.

50. See id. at $442-43$.

51. See Am. Bar Ass'n Comm'n on Mental Health and Physical Disability law, The National Conference on the Employment of Lawyers with Disabilities: A Report from the American Bar Association for the Legal Profession (2006), available at http://www.abanet.org/ disability/docs/conf_report_final.pdf [hereinafter ABA REPORT].

52. Id. at 3 .
} 
Disabilities Act (ADA) ${ }^{53}$ Thornburgh cited several studies showing the rate of employment for people with disabilities to be dramatically lower than the employment rate for non-disabled people. ${ }^{54} \mathrm{He}$ made it clear that the legal profession is no exception:

\footnotetext{
Regrettably, lawyers with disabilities continue to face discrimination. Nearly half of the respondents of a recent survey by the State Bar of California's Committee on Legal Professionals with Disabilities believed that they were denied employment opportunities because of their disabilities. Many of them indicated that they were denied jobs even though they graduated in the top 10 to 20 percent of their law school classes at higher-ranked schools than those who eventually received job offers. Some survey respondents indicated that law firms that had extended job offers to them revoked the offers once the firms discovered an individual's disability. ${ }^{55}$
}

One of the things the conference achieved was to promulgate several sets of recommendations. Conference participants and the ABA Commission on Mental and Physical Disability Law developed recommendations for legal employers as guidance during the application and hiring processes ${ }^{56}$ that would, if implemented by prospective employers, go a long way toward eliminating the employment gap between lawyers with and without disabilities. I have included the text of the recommendations as Appendix I to this Article.

\section{Survey of Georgia Law Students}

I was curious to see whether the job interview experiences reported by Georgia law students would parallel those reported by the groups in the articles examined above. With the help of the Survey Research Center at the University of Georgia, I designed a survey instrument to answer that question. I wanted responses from all law students who had interviewed for law-related jobs, not just law students with disabilities. I wanted to see what differences in experience and perception, if any, existed between students with and without disabilities. The full survey instrument is included as Appendix II.

The survey was sent in March 2007 by email to the students of the five accredited law schools in Georgia-Emory, Georgia State University, John Marshall, Mercer University, and the University of Georgia. If all of the

53. Id. at 4 .

54. Id. at 10 .

55. Id. at 10-11.

56. See id. at 61-62. 
students in all of the law schools had received the survey, approximately 2,811 students would have received the survey. Due to institutional polices at one of the law schools, however, the survey was not disseminated to the entire student body, but only to just over one-fifth of the student body. I believe that approximately 2,280 students actually received the survey. Two hundred eighty-seven students responded, a response rate of $12.6 \%$. A return rate of $10 \%$ to $20 \%$ is the norm on surveys of this kind.

Almost $80 \%$ of the respondents were second-and third-year law students, an imbalance that is probably due to the survey having targeted only students who interviewed for jobs in law-related fields. Many first-year students may not have yet done any law-related interviewing. The average age of respondents was twenty-six. Fifty-eight percent of respondents were female, $82.4 \%$ were white, and $94.3 \%$ were heterosexual. Approximately $95 \%$ of respondents reported no disability under any of the three definitional prongs of the ADA. ${ }^{57}$

Twelve students reported having a disability under the first prong qualification, having a current impairment. Twelve students reported having a record of disability (prong two), and fourteen students reported having a condition that might be regarded as a disability (prong three). The categories are not mutually exclusive, so it is impossible to say how much overlap there was among these respondents. The total number of respondents on subsequent questions would suggest that somewhere between fourteen and twenty students with disabilities responded to the survey. Half of the students who reported having a disability said their disability would not be evident to someone who meets them for the first time, and $80 \%$ said it would not be evident to anyone who talks to them on the telephone. The large proportion of hidden disabilities among these respondents probably accounts for their surprising answers as to when they disclose their disability to an employer. Of respondents with prong-one disabilities, $55.6 \%$ do not disclose them to their employer at all. A similar number of "regarded as" respondents, 54.5\%, do not disclose, and $43.5 \%$ of respondents with a record of disability never disclose the disability to their employers. The students who do disclose their disability most often do so at the interview stage. The next most frequent answer was "After receiving an offer."

I was curious whether the issue of disability came up either directly or indirectly during interviews, and if it did come up, who raised it. Approximately $74 \%$ of students with disabilities reported that no interviewers

57. See 42 U.S.C. $\S 12102(2)(2000)$. 
asked questions about their health and stamina, and 57.9\% recalled no inquiries about their ability to work long hours. Eight students did report receiving questions about health, stamina, and ability to work long hours. Although the questions were not explicitly aimed at discovering the student's disability, $75 \%$ of disabled students believed that this was the purpose of such questions. One student reported that disability was explicitly discussed in all her interviews, one reported that it was discussed in more than half, and two reported that it was discussed in less than half the interviews. Only two students reported interviewers who discussed reasonable accommodations. Interviewers raised the issues of disability or reasonable accommodation in half of the reported discussions, while respondents raised the issue in the other half.

I wanted to know whether law students with disabilities believed they had been discriminated against because of their disability. Approximately $78 \%$ did not believe that any of the potential employers rejected them because of their disability, $52.6 \%$ reported that they were employed or had a job offer, and $68.4 \%$ of those employed believe that their job was equivalent to the jobs of similarly qualified but not disabled law students.

Another objective of my survey was to discover whether non-disabled law students have the same types of interviewing experiences reported by students with disabilities. It would appear that their experiences differ somewhat. Only eight non-disabled students out of 225 reported questions about health and stamina (compared to five out of nineteen among disabled students). Twenty-five out of 226 reported questions about ability to work long hours (compared to eight out of nineteen among disabled students). Only a tiny fraction of non-disabled students - four out of 185 - believed those questions were aimed at discovering disability (compared to six out of eight among disabled students). In only four cases out of 225 did non-disabled students report that the interviewer explicitly discussed disability in an interview (compared to four out of nineteen among disabled students).

My final inquiry was whether non-disabled students are more likely to be employed and whether their jobs are equivalent to ones offered to disabled students. The survey results indicated that $65.2 \%$ of non-disabled students had jobs or job offers, and $72.7 \%$ believed their jobs were the equivalent of their disabled colleagues' jobs.

The survey included an open-ended question that invited respondents to say anything they wanted on the topic of interviewing and disability. One student with a visible disability of an unspecified type reported being asked whether he dictated or typed his work. When he said he typed over fifty words a minute on a regular laptop, the interviewer accused him of lying. 
This same student, who was in the top twenty percent of his class, had fifty interviews and no job offers. He believed firms chose to go with less qualified candidates out of fear of having to accommodate. The job offer he accepted, a prestigious appellate court position, came through a family contact who attested to his abilities. He ends his comment with a cri de coeur: "I think given how my disability looks, firms think I am incapable of performing their caliber of work. To which I would ask, 'How then do you think I am in the top $20 \%$ of my class?' VERY FRUSTRATING!!”

Another student who interviewed with a male judge reported that the judge asked her if she had any disabilities. She wondered whether that was a legitimate question, but she told him she had ulcerative colitis. The judge continued to talk about it during the rest of the interview even after she told him that it was a mild case and was controlled by medication. He offered the job to someone else, although she did not believe it was because she had colitis. She seemed to go out of her way to excuse the judge: "Probably the question was just because the judge was a bit eccentric."

A student who took medication for panic attacks said he was sure that he didn't meet the definition of being disabled, but that he would not mention his panic attacks out of fear that an employer would view them as a hindrance in litigation, public speaking, and maybe even passing the bar exam. That same student went on to say, "I have heard of many disabled students who believe they can only go into tax work or other less client-interactive positions because law firms don't want them out 'in public."'

Three different women told of being interrogated by interviewers about their plans to have children. One said, "I know that child-bearing isn't included on the list of disabilities, but should it be since some employers treat it that way?" Another said, "My experiences lead me to believe that being a woman who may potentially become pregnant has really hurt my marketability. I have basically given up working for a law firm. I realize that this is more of a sex discrimination issue, but fertility ought to be considered a disability if it prevents women from getting jobs and it is a physical condition." The third said, "[T]here was a strong indication that if I got pregnant it would be a problem."

Eight students (out of thirty-eight who wrote comments) said explicitly that there was no mention of disability, direct or indirect, in any of their interviews. Three students found it difficult to answer the question about whether their jobs were equivalent to the jobs offered to others - one of them was so frustrated by the question that he apparently wanted me fired for doing the survey: "I am really glad that taxpayer money is being used to fund this crap." My wounded feelings were soothed when I read the following 
comment: "I never knew my problems qualified me to be considered disabled. Thank you for this survey. . . . I am going to seek accommodation. . . . No one has ever been rude at an interview, but I think my problems probably resulting [sic] in my receiving fewer interviews and callbacks than people who are healthy." One student said succinctly, "Law school interviewing is horrible."

\section{CONCLUSION}

I have reached four cautious conclusions from my survey. First, it appears that there is rarely any discussion of disability in law school interviews, particularly in interviews with non-disabled students. Without more information, it is difficult to say whether the failure to discuss disability indicates interviewer bias. It may simply mean that interviewers do not realize that the incidence of disability is as high as it is, so they don't see discussing disability-related policies as a high priority during interviews.

Second, law students appear to be very reluctant to disclose their disabilities to potential employers. I was surprised that these numbers were so high, since reasonable accommodation will not be available to those who choose to keep their disabilities a secret. The rate of non-disclosure reminds me of the decisions of gay and lesbian attorneys to stay in the closet because the stigma of being gay puts them at a competitive disadvantage. It would seem that a large number of law students with disabilities believe that disability carries a stigma that would disadvantage them more than the legal rights created by the ADA would help them.

Third, the experiences and perceptions of disabled law students differ from the experiences and perceptions of non-disabled law students. Students with disabilities were less likely to have a job or job offer ${ }^{58}$ and were less likely to believe their jobs were the equivalent of non-disabled colleagues' jobs.

Fourth, interviewers discussed disability with the disabled applicants more often than they did with non-disabled applicants, although there was little discussion regarding the issue in general.

58. Still, the $12.6 \%$ employment gap found in my survey is considerably smaller than the $43 \%$ gap in the population at large that was cited by Mr. Thornburgh in his keynote address. See ABA RePORT, supra note 51, at 10 . 


\section{Appendix I}

\section{Recommendations from the American Bar Association National Conference on the Employment of Lawyers with Disabilities: For Legal Employers During the Application and Hiring Process}

1. Appoint a diversity representative on your firm's management committee (or in that component of a human resource department that does legal hiring for an agency, organization, or corporation) who is well-versed in disability issues.

2. Understand the requirements of the ADA and any applicable state disability discrimination laws when planning and implementing your hiring and retention procedures, and creating a productive work environment for your lawyers with disabilities. (Perhaps the most important rule is that during the pre-offer stage you should allow the candidate to raise the issue of disability or not, and only to the extent that the candidate wishes to discuss that issue.)

3. In your job announcements, make people with disabilities a part of the equal opportunity language that you use, and make sure that the announcements are sent in print and electronic formats that will make them accessible to persons with visual, manual, mobility, and other relevant disabilities. Also, recognize that in order to encourage diverse applications, it is useful to target locations that are likely to be used by members of diverse groups, including persons with disabilities who, for example, may be more likely to utilize the Internet and websites than other candidates.

4. When deciding how to populate your work environment with lawyers, write job descriptions that closely reflect those specific tasks that you view as essential, so that persons who may have outstanding oral, writing, or computer legal research skills, but may be less proficient with regard to one of the other areas, will not be automatically excluded from consideration. Also, you should be judging all candidates primarily on how they will perform essential job functions.

5. When preparing job descriptions for the lawyers you want to hire, ensure that your list of minimum qualifications are not higher than they need to be for the position that you are trying to fill.

6. In the interview process, ask questions that bring out the candidate's strengths first and then, if necessary, delve into his or her possible limitations. In determining who is qualified, focus on essential functions of the position, rather than general disqualification measures such as grade point average, law review, and/or LSAT scores.

7. If and when you feel it is necessary to consider law school grade point averages, LSAT scores, and law review participation, remember that these are convenient, but often inaccurate or under-inclusive measures of legal potential, particularly for law students with disabilities, law students who must work while in school, and law students who were at a distinct academic disadvantage when they started but who have continued to improve while in law school.

8. When deciding whether to hire lawyers, make a list of their strengths in relation to the essential job functions, and make the best case for how each qualified applicant might help your firm, agency, department, or organization before examining their potential limitations. 
9. When considering the limitations of any qualified lawyer who applies for a position at your firm, agency, department, or organization, think about how you as the employer can help the potential employee overcome those limitations and become productive in your employment milieu.

Am. Bar Ass'n Comm'n on Mental Health and Physical Disability Law, The National Conference on the Employment of Lawyers with Disabilities: A Report from the American Bar Association for the Legal Profession 61-62 (2006), available at http://www.abanet.org/ disability/docs/conf_report_final.pdf. 


\section{ApPENDIX II}

\section{Dear Law Student:}

You are invited to participate in a research study titled "Law Student Interviewing Experiences 2007" conducted by James Bason, Ph.D., Director and Associate Research Scientist; 706-542-9082, jbason@uga.edu), on behalf of Dr. Ann Puckett, Professor of Law at the University of Georgia Law School.

The purpose of this research study is to examine how both interviewers and interviewees approach questions about disability. Students with or without disabilities at any stage of their law school careers are invited to participate if, while law students, they interviewed for a full time job (including summer associate jobs) in a position requiring legal training.

If you should choose to participate in this study, you will complete an online survey that includes basic demographic questions and questions regarding your interviewing experiences and questions about disabilities.

Completion of the survey is expected to take approximately 10 minutes. Please note that Internet communications are insecure and there is a limit to the confidentiality that can be guaranteed due to the technology itself. However, any information that is obtained in connection with this study will remain completely anonymous and no participant will be individually identified. Your participation in this study is completely voluntary. You may withdraw at any time without penalty, or skip any questions you feel uncomfortable answering. There is no more than minimal risk anticipated with participation in this study, and there is expected to be no tangible benefit for you as a result of participation in this study.

If you have any questions do not hesitate to ask now or at a later date. You may contact James J. Bason, Director and Associate Research Scientist at 706-542-9082 or jbason@uga.edu.

Thank you for the invaluable help that you are providing by participating in this research study. It is expected the results of this study will be presented at a conference on disability in the legal profession in September, 2007, at Emory University. 
Sincerely,

James J. Bason, Ph.D.

Director and Associate Research Scientist

Survey Research Center

University of Georgia

Additional questions or problems regarding your rights as a research participant should be addressed to The Chairperson, Institutional Review Board, University of Georgia, 612 Boyd Graduate Studies Research Center, Athens, Georgia 30602-7411;

By clicking on the 'BEGIN SURVEY' button below you are agreeing to participate in the research.

\section{BEGIN SURVEY}

\section{Demographic Questions}

Q1 - Please select the year that describes your current year in law school.

1. First Year

2. Second Year

3. Third Year

4. Graduate Student

5. Choose not to answer

Q2 - Please select your gender.

1. Male

2. Female

3. Choose not to answer

Q3 - Please enter your current age.

years old 
Q4 - Please indicate your race/ethnicity.

\section{Mixed}

2. Latino/Other Hispanic

3. Black/African-American

4. Asian American/Pacific Islander

5. East Indian/Pakistani

6. American Indian/Native American

7. White/Caucasian

8. Other

9. Choose not to answer

Q5 - Please indicate your sexual orientation.
1. Heterosexual
2. Gay/Lesbian
3. Bisexual
4. Transsexual
5. Choose not to answer

Please read the following definitions carefully. You will be asked to answer questions later that refer to these definitions.

The Americans with Disabilities Act defines "disability" this way:

The term "disability" means, with respect to an individual-

(A) a physical or mental impairment that substantially limits one or more of the major life activities of such individual;

(B) a record of such an impairment; or

(C) being regarded as having such an impairment

42 U.S.C. § 12102(2) (2006).

The EEOC regulations pursuant to the ADA define "physical or mental impairment" as:

(1) Any physiological disorder, or condition, cosmetic disfigurement, or anatomical loss affecting one or more of the following body systems: neurological, musculoskeletal, special sense organs, respiratory (including speech organs), cardiovascular, reproductive, digestive, genito-urinary, hemic and lymphatic, skin, and endocrine; or 
(2) Any mental or psychological disorder, such as mental retardation, organic brain syndrome, emotional or mental illness, and specific learning disabilities.

29 C.F.R. § 1630.2(h) (2007).

The EEOC regulations pursuant to the ADA define "Major Life Activities" as:

... functions such as caring for oneself, performing manual tasks, walking, seeing, hearing, speaking, breathing, learning, and working.

29 C.F.R. § 1630.2(i) (2007).

Given these definitions. ...

Q6 - Do you currently have an actual disability under prong A of the definition above?

1. Yes

2. No

3. Choose not to answer

Q7 - Do you have a record of disability under prong B of the definition above?

1. Yes

2. No

3. Choose not to answer

Q8 - Do you have a condition that could lead someone to regard you as disabled under prong $\mathrm{C}$ of the definition above?

1. Yes

2. No

3. Choose not to answer

[PROGRAMMER: IF Q6 or Q7 or Q8 = 1, ask Q9 - Q23; otherwise skip to Q25] 
Q9 - How evident is your disability to anyone who meets you for the first time?

1. Very evident

2. Somewhat evident

3. Only slightly evident

4. Not evident at all

Q10 - How evident is your disability to anyone who talks to you on the telephone?

1. Very evident

2. Somewhat evident

3. Only slightly evident

4. Not evident at all

Q11 - At what point do you disclose your disability to prospective employers? [PROGRAMMER; ASK ONLY IF Q6 = 1]

[PLEASE CHOOSE ALL THAT APPLY]

1. Pre-application networking

2. On the resume

3. When arranging an interview

4. During the interview

5. After the interview in follow-up communications

6. After receiving an offer

7. Do not disclose

Q12 - At what point do you disclose your record of disability to prospective employers?

[PROGRAMMER; ASK ONLY IF Q7 = 1]

\section{[PLEASE CHOOSE ALL THAT APPLY]}

1. Pre-application networking

2. On the resume

3. When arranging an interview

4. During the interview

5. After the interview in follow-up communications

6. After receiving an offer

7. Do not disclose 
Q13 - At what point do you discuss with a prospective employer the condition that could lead someone to regard you as disabled?

[PROGRAMMER; ASK ONLY IF Q8 = 1]

\section{[PLEASE CHOOSE ALL THAT APPLY]}

1. Pre-application networking

2. On the resume

3. When arranging an interview

4. During the interview

5. After the interview in follow-up communications

6. After receiving an offer

7. Do not discuss

Q14 - During any of your interviews, did the interviewer ask questions about your health and stamina?

1. All of them

2. More than half of them

3. Less than half of them

4. None of them

Q15 - During any of your interviews, did the interviewer ask questions about your ability (as opposed to willingness) to work long hours, or to travel, or to do any other unusually strenuous part of the job?

1. All of them

2. More than half of them

3. Less than half of them

4. None of them

[PROGRAMMER: SKIP Q16 ONLY IF Q14 AND Q15 = 4]

Q16-In how many of the interviews do you believe the inquiries were related to disability as defined under any of the three prongs?

1. All of them

2. More than half of them

3. Less than half of them

4. None of them 
Q17 - If you have a disability under any of the three prongs, in how many interviews did you discuss it during the interview?

1. All of them

2. More than half of them

3. Less than half of them

4. None of them [SKIP TO Q19]

Q18 - Who opened the discussion of your disability in these interviews?

1. Interviewer opened the discussion

2. You opened the discussion

Q19 - In how many of the interviews did you discuss reasonable accommodations in the interview?

1. All of them

2. More than half of them

3. Less than half of them

4. None of them [SKIP TO Q21]

Q20 - When you discussed reasonable accommodations, who opened the discussions?

1. Interviewer opened the discussion

2. You opened the discussion

Q21 - In how many interviews do you believe employers declined to offer you a job because of your disability?

1. All of them

2. More than half of them

3. Less than half of them

4. None of them

Q22 - Are you presently employed or do you have a job offer in a field requiring legal education?

1. Yes

2. No 
Q23 - Do you believe your job or job offer is equivalent to those of your similarly qualified but non-disabled classmates?

1. Yes

2. No

Q24 - Please provide any narrative description of interview experiences you want us to know about for this survey.

PROGRAMMER: END INTERVIEW WITH, "Thank you for taking time to participate in this important survey"; then link back to UGA Law School web site.

Q25 - During any of your interviews, did the interviewer ask questions about your health and stamina?

1. All of them

2. More than half of them

3. Less than half of them

4. None of them

Q26 - During any of your interviews, did the interviewer ask questions about your ability (as opposed to willingness) to work long hours, or to travel, or to do any other unusually strenuous part of the job?

1. All of them

2. More than half of them

3. Less than half of them

4. None of them

Q27 - If any interviewers asked the questions referred to in the previous two questions, do you believe the inquiries were related to disability as defined under any of the three prongs?

1. All of them

2. More than half of them

3. Less than half of them

4. None of them 
Q28 - Did the interviewers broach the subject of disability during the interviews? (e.g., describe the employer's policy regarding employees with disabilities).

1. All of them

2. More than half of them

3. Less than half of them

4. None of them

Q29 - Are you presently employed or do you have a job offer in a field requiring legal education?

1. Yes

2. No

Q30 - Do you believe your job or job offer is equivalent to those of your similarly qualified but disabled classmates?

1. Yes

2. No

Q31 - Please provide any narrative description of interview experiences you want us to know about for this survey.

Thank you for taking time to participate in this important survey. 